\title{
Novelty and grooming behavior in the rat
}

Citation for published version (APA):

Jolles, J., Rompa-Barendregt, J., \& Gispen, W. H. (1979). Novelty and grooming behavior in the rat. Behavioral and neural biology, 25, 563-572. https://doi.org/10.1016/S0163-1047(79)90362-5

Document status and date:

Published: 01/01/1979

DOI:

10.1016/S0163-1047(79)90362-5

Document Version:

Publisher's PDF, also known as Version of record

\section{Please check the document version of this publication:}

- A submitted manuscript is the version of the article upon submission and before peer-review. There can be important differences between the submitted version and the official published version of record.

People interested in the research are advised to contact the author for the final version of the publication, or visit the DOI to the publisher's website.

- The final author version and the galley proof are versions of the publication after peer review.

- The final published version features the final layout of the paper including the volume, issue and page numbers.

Link to publication

\footnotetext{
General rights rights.

- You may freely distribute the URL identifying the publication in the public portal. please follow below link for the End User Agreement:

www.umlib.nl/taverne-license

Take down policy

If you believe that this document breaches copyright please contact us at:

repository@maastrichtuniversity.nl

providing details and we will investigate your claim.
}

Copyright and moral rights for the publications made accessible in the public portal are retained by the authors and/or other copyright owners and it is a condition of accessing publications that users recognise and abide by the legal requirements associated with these

- Users may download and print one copy of any publication from the public portal for the purpose of private study or research.

- You may not further distribute the material or use it for any profit-making activity or commercial gain

If the publication is distributed under the terms of Article $25 \mathrm{fa}$ of the Dutch Copyright Act, indicated by the "Taverne" license above, 


\title{
Novelty and Grooming Behavior in the Rat
}

\author{
J. Jolles, J. Rompa-Barendregt, AND W. H. Gispen ${ }^{1,2}$ \\ Division of Molecular Neurobiology. Rudolf Magnus Institute \\ for Pharmacology and Laboratory for Physiological Chemisry. Medical \\ Faculy, Institute of Molecular Biology, Paduatan 8, \\ Utrecht, The Netherlands
}

\begin{abstract}
Exposure to novelty (preobservation transportation, injection, and novel enviromment) enhances the display of grooming behavior in the rat. Enhanced grooming is still observed after repeated exposure during 5 consecutive days and does not result in a diminished behavioral response. As bypophysectomized animals also show novelty-induced grooming it is concluded that the behavioral response does not depend on integrity of the pituitary-adrenal system. Analysis of the temporal aspects of the behavior reveals a difference in the effects of environmental stimuli present before or during behavioral analysis and it is argued that the displayed behavior may be related primarily to the activating infutence of environmental stimuli.
\end{abstract}

Grooming behavior is a major activity during the nonsleeping time of the rat (Bolles, 1960). Cleaning the fur, a maintenance behavior, is very important for rodents as in this manner the natural boundary between internal and external milieu is kept in good condition (Cannon, 1932: Svenson \& Randall, 1977).

Elements of the maintenance repertoire can also be observed in situations in which the maintenance of the skin and fur seems less important. First, there seems to be a relation between grooming behavior and temperature regulation as many small mammals, especially rodents, groom in order to lose heat (Adolph, 1947; Hainsworth, 1967). Second, grooming behavior is often displayed as reaction to unexpected stimuli (Fentress, $1968 \mathrm{a}, \mathrm{b}$, vole), in conflict situations (van lersel \& Bol, 1958, tern; Rowell, 1961, chaffinch), or in frustration (McFarland, 1966, dove). A common element in these situations seems to be the presence of potentially stress-

Correspondence should be sent to Dr. W. H. Gispen, Division of Molecular Neurobiology, Institute of Molecular Biology. State Uniwersiry of Utrecht, Padualaan 8. Utrecht, The Netherlands.

${ }^{2}$ The authors wish to thank Drs. D. de Wied and J. L. Slangen for valuable suggestions and discussions and Mr. J. Brakkee for his indispensable technical assistance. 
ing or novel stimuli or stimuli that bear conflicting information. This stress-and conflict-related grooming is described as a displacement activity (Sevenster, 1961; Tinbergen, 1940).

Of course, novel stimuli as well as stressful stimuli are known to activate the pituitary-adrenal system (see Mason, 1968a,b). This relationship between stress/novelty and grooming as displacement activity becomes the more interesting in view of the potency of ACTH and related pituitary peptides $\left(\mathrm{ACTH} \mathrm{I}_{1-2 \mathrm{~A}}, \alpha \mathrm{MSH}, \beta \mathrm{MSH}\right)$ to induce excessive grooming upon intraventricular adminstration (Gispen, Wiegant, Greven, and de Wied, 1975; Wiegant \& Gispen, 1977). In order to gain more information on mechanisms involved in normal, and peptide-induced grooming behavior it was decided to study the relationship between environmental events and grooming behavior in more detail.

\section{METHODS}

Subjects and experimental procedure. Malle rats of an inbred Wistar strain were used (TNO, Zeist, The Netherlands). They were bred in our own colony and weighed $140-150 \mathrm{~g}$ at the commencement of the experiment. The animal rooms were kept at a normal 12-hr light/12-hr dark schedule (8:00 A M/8:00 PM). The rats were handled every second day. All experimental animals were housed individually in plastic boxes with wood shavings on the floor for 1 week prior to the experimental day. Cannulation took place 1 week before the experimental day. All experiments were performed between 10:00 AM and 3:00 PM. On the experimental day a standard grooming test was run as follows: Circa 10 cages were transported from the animal room to the behavior observation room. This transport took 2 to $4 \mathrm{~min}$. Then the rats received an intraventricular injection after which they were subjected to the behavioral analysis in a dimly lit soundproof observation room. Observation was carried out through a one-way mirror. Eight to ten rats were observed simultaneously. In the experiments the following procedural elements were varied.

\section{A. Preobservation treatment}

Transport: transport on a cart between animal room and observation room

Injection: intracerebroventricular injection of saline $(3 \mu \mathrm{l})$

B. Environment

Novelty: placement in a novel box either in a novel sound proof room or in the familiar animal room

Swgery and injection. Surgery was performed under light Hypnorm ${ }^{\mathrm{R}}$ anesthesia (Philips Duphar, Amsterdam, The Netherlands). A plastic cannula $(\phi, 0.357 \mathrm{~mm}$, depth, $4.5 \mathrm{~mm})$ was implanted into the interven- 
tricular foramen (where the third and lateral ventricles merge) using stereotactic coordinates according to König and Klippel (1963; Colbern, Isaacson, Bohus \& Gispen, 1977). The cannulas were fixed to the skull with dental cement. Hypophysectomy was performed using the transauricular route. Animals that had to be both cannulated and hypophysectomized received both surgeries in one session.

Intracerebroventricular (icv) injections were made by free hand into conscious rats using a microsyringe (Colbern et al, 1977). Injection volume was $3 \mu$ l. For all injections a $0.9 \%$ saline solution was used.

Behavorial analysis. After manipulation (injection) the rats were placed individually into glass boxes $(24 \times 12.5 \times 14 \mathrm{~cm})$. This moment marked the beginning of the behavorial session. Behavior was recorded between 15 and $65 \mathrm{~min}$ thereafter as described previously (Gispen et al., 1975), unless stated otherwise. In short, every 15 th second the observer recorded whether the animal displayed an element of the maintenance repertoire (vibrating, washing, grooming, scratching, licking body, licking paw, or licking tail). If one of the elements was observed at the 15 th second, a positive score was given. Since the predominant element recorded is grooming we refer to grooming in keeping with previous reports (Gispen et al., 1975; Colbern et al., 1977). Thus, in a 50-min observation period a maximum of 200 positive grooming scores can be obtained provided that one scores every 15 th second. Scores are given as the percentage of this maximum possible grooming score. The validity of this time sampling technique has been established elsewhere (Gispen et al., 1975). In one experiment, as an estimate index of "emotionality" produced by treatment and environment, urination/defecation scores were taken as described by Broadhurst (1960). A positive score was assigned to that animal that urinated and/or defecated during the manipulation or within 2 min thereafter.

Statistics. The differences between groups were tested with the Walsh test, Kruskal-Wallis one-way analysis of variance and Mann-Whitney $U$ test (Siegel, 1956) and were assigned to be significant for values of $p<$ 0.05 , one tailed.

\section{RESULTS}

\section{Effects of Novelty and Preobservation Treatments on Grooming}

In this experiment we tested the grooming-inducing potency of variables present in our standard grooming behavior observation procedure (Gispen et al., 1975; Colbern et al., 1977).

Eight groups of rats were used. These groups received a treatment differing from standard treated rats in the variables "novel environment," (preobservation) "transport," and (preobservation) injection (see Methods and Fig. 1). The only common treatment all animals received is 5 sec of manipulation by the experimenter before placement in the observa- 


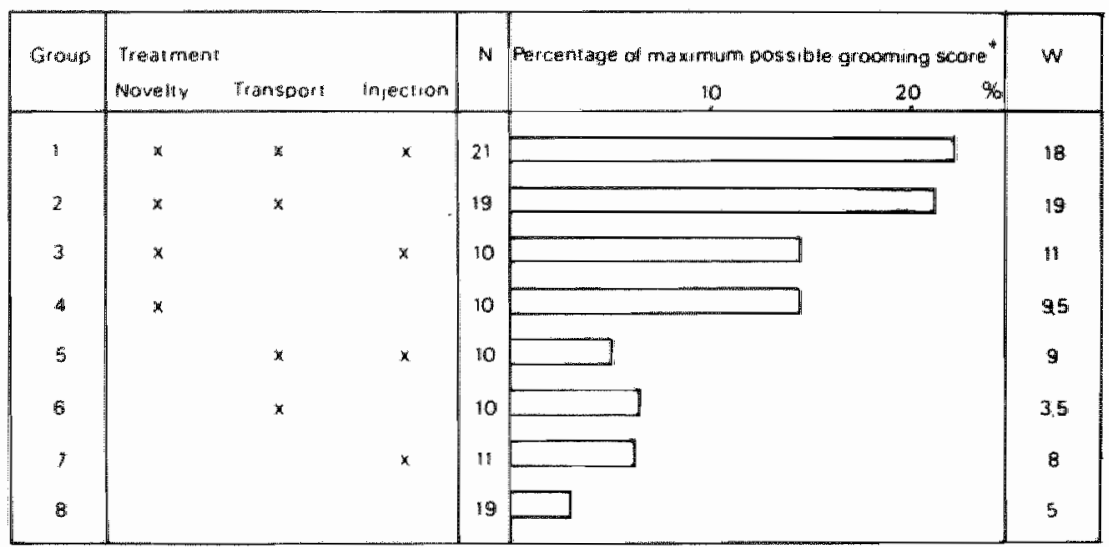

Fio. 1 . Effect of nowel environment and preobservation treatmeni on grooming behavior. N N Number of animils; W, interquartile range; +Median grooming score.

tion box. Figure 1 shows the median grooming scores for the elight groups of subjects. A Kruskal-Wallis one-way analysis of variance applied to these data revealed the presence of significant effects $(H=43.8 ; p<$ $0.001)$. As is immediately evident from the figure, there is a substantial increase in grooming in all novelty conditions (groups 1 through 4) compared to the nonnovelty conditions (groups 5 through $8 ; p<0.004$, Mann-Whitney $U$ test). There is no difference between the four novelty groups. Thus rats which were placed in a novel box in the familiar animal room (group 4) displayed a similar amount of grooming as rats that, after being transported to a new observation room, were injected and placed in a novel box (group 1). Injection and preobservation transport by themselves do not add to the novelty-induced grooming (groups 2 and 3). Yet transport, injection, and their combination significantly induce grooming when the animal is observed in its home environment (group 8 , no treatment group; group 5, 6, and 7 vs 8; Mann-Whitney $U$ test, $p=0.05, p<$ $0.02, p=0.05$, respectively).

\section{Hypophysectomy, Novelty, and Grooming}

The possible role of the pituitary in mediating the effect of environmental stimuli on grooming was studied by subjecting hypophysectomized animals to the relevant experimental conditions used in the previous experiment.

Two groups of hypophysectomized rats were used. One group of animals ( $N=9$, cannulated) received a standard grooming test as described (Methods). Animals in the other group ( $N=9$, cannulated) were not transported but, after receiving an icv injection, were observed in their home cage in the animal room. It appeared that hypophysectomized animals groom significantly more when placed in a completely new envi- 
ronment, than when in their home environment (Fig. 2A, Mann-Whitney $U$ test, two-tailed, $p<0.02)$. This result was found in a number of experiments, in both cannulated and non-cannulated, non-injected animals (data not shown). Hypox animals are more active during the observation period than normals and spend more time in motoractivity (Gispen, van der Poel \& van Wimersma Greidanus, 1973). They are awake for a longer proportion of the observation time which could contribute to the fact that the hypox animals show higher grooming scores than intact rats. Thus in rats, irrespective of an intact, functioning pituitary-adrenal system, novelty and/or preobservation treatment induce grooming behavior. In a subsequent experiment the influence of novelty per se on grooming was further analyzed by subjecting the animals five times to the standard experimental treatment and comparing the grooming scores obtained on the first day to those on the last day of treatment. As an index of "emotionality", their urination/defecation scores were taken as described (Methods). As is clear from Fig. 2B, the training of the animals results in a marked decrease in emotionality score, whereas only a slight but not significant reduction in grooming occurs over the training period (Walsh test). Thus it shows that in rats "emotionality" induced by the novel treatment is not a prerequisite for novelty-induced grooming.

\section{Novelty and Grooming: Temporal Aspects}

Previously, studies on displacement grooming have largelly focused on the effect of an unexpected, novel, or conflicting stimulus on the behavior during a $15-\mathrm{min}$ period immediately following the presentation of that stimulus (e.g., Bindra, 1956; Bolles, 1960) while our standard grooming test does not take these first $15 \mathrm{~min}$ into consideration. The reason is that our standard grooming test was applied in studies focused on drug-rather than procedure-induced grooming.

In the preceding paragraphs effects of various experimental treatments

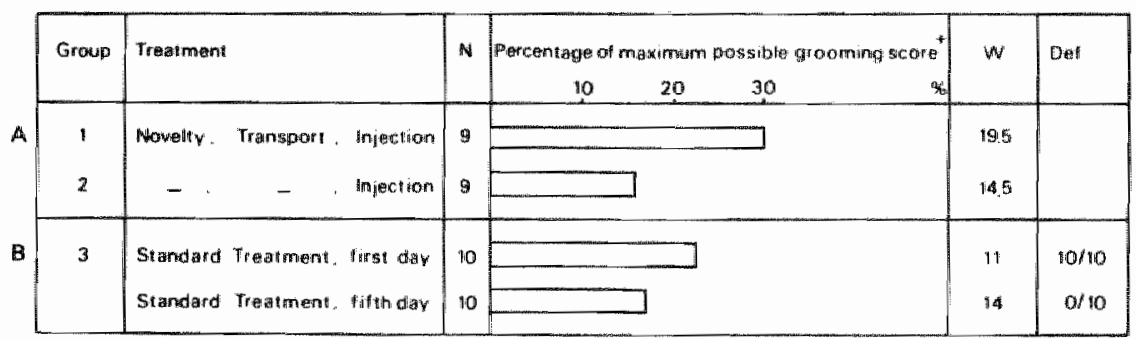

Fic. 2. (A) Effect of novel environment and preobservation treatment on grooming in hypophysectomized animals. (B) Effect of training on grooming scores. $N$. Number of animals; $W_{\text {n }}$ interquartile range; Def, incidence of urination/defecation a positive score was assigned to that animal that urinated andior defecated during injection or within 2 min thereafter; Median grooming score. 
on grooming behavior were described: the animal displayed more grooming behavior in a novel situation than in its home environment. Potentially stressful stimuli prior to observation had a similar effect. Therefore, some relevant experimental conditions were reevaluated with respect to grooming induction using a behavior analysis starting immediately after manipulation.

Figure 3 depicts the temporal pattern of grooming behavior displayed by novelty and/or preobservation treatment groups: Untreated animals observed in the home environment (group 4) begin to groom immediately after the manipulation: they soon stop grooming and invariably fall asleep (total grooming score, $8.5 \%$ ). Untreated animals however, when placed into the novel glass box freeze and/or start exploring (group 2). Only gradually they commence grooming, interrupted by periods of freezing behavior and exploration; but this group exhibits a significantly elevated total grooming score ( $22 \%$ ) because they engage in grooming behavior for a much longer period of time. Animals that have been exposed to preobservation treatment, when put back into their home cage after transportation (group 3), show enhanced grooming immediately after this manipulation (total grooming score, $15 \%$ ) but stop grooming at a time similar to that for nontreated animals (group 2). Animals exposed to both preobservation treatment and novelty (group 1) show both the increase in grooming immediately after injection (although somewhat later than in the corresponding nonnovelty group) and the prolonged grooming induced by the novel environment: their total grooming score is $24 \%$. These results suggest that the effect of potentially stressful stimuli prior to the observa-

Positive girooming scores
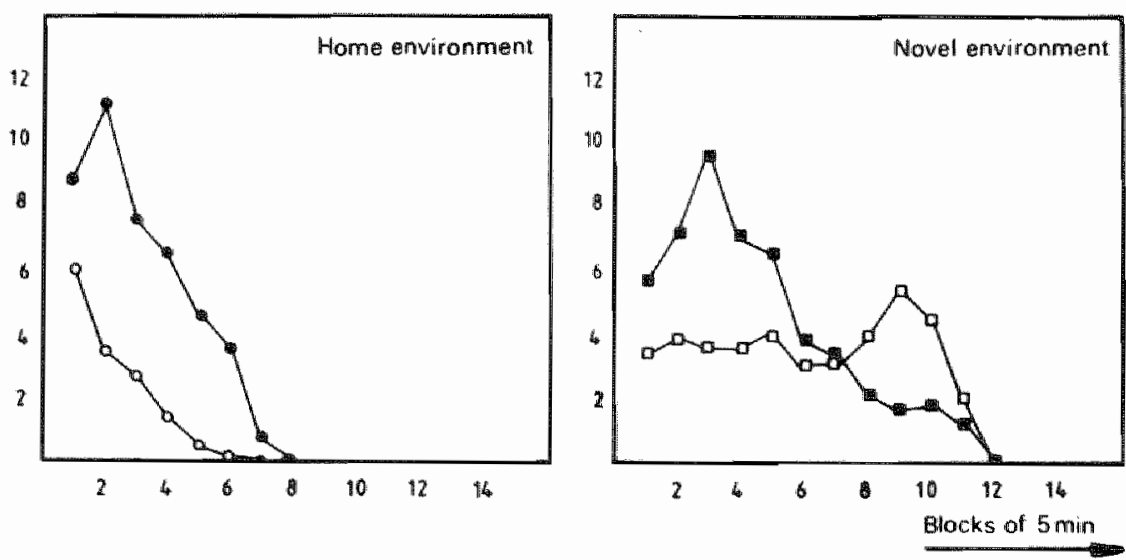

Fro. 3. Temporal pattern of grooming behavior after preobserwation treatment and/or novelty. Group 1( novelty and preobservation treatment (standard treatment); Group $2(\mathrm{C})$ only noveliy; Group 3 ( only preobservation treatment; and Group $4(0)$ no treatment. Median grooming scores are given per block of $5 \mathrm{~min}$. 
tion is manifest immediately after disappearance of these stimuli, and that the effect of novel environment is manifest throughout the observation period, the period that these novel stimuli are present.

\section{DISCUSSION}

When rats were handled for a few seconds they manifested grooming behavior in the first $20 \mathrm{~min}$ after manipulation, with a grooming score of $8.5 \%$ (Fig. 3). When exposed to varying novel/stressful stimuli their grooming score was enhanced to 15 to $24 \%$. All experimental groups are manipulated (handled to the same extent: we conclude therefore that maintenance behavior (cleaning the disarranged fur) maximally accounts for $8.5 \%$ of total grooming score, so maintenance grooming cannot explain the enhanced and prolonged grooming observed in treated rats (novel environment and preobservation treatment). The "extra" grooming may then be regarded as a novelty and stress-related displacement activity (Fentress, 1968a,b; McFarland, 1966; Rowell, 1961; Sevenster. 1961: Tinbergen, 1940; Van lersel \& Bol, 1958). In a recent study also Colbern, Isaacson, Green and Gispen (1978) described environmentinduced increases in grooming behavior in the rat. They reported an enhanced display of grooming in a novel vs. home environment; switching the rats from novel to home enviromment is paralleled by a drop in grooming activity.

Although Dunn (personal communication) found no novelty-induced grooming in hypophysectomized rats, in our hands these animals showed a similar increase in grooming activity upon preobservation treatment and novelty. As intact animals show enhanced grooming even when they do not seem to respond "emotionally" any more to the experimental treatment after 5 days of experience (Fig. 2), this may suggest that pituitaryadrenal activity is not the essential factor in the induction of grooming behavior. Likewise, extensive studies by others on the relation between various manipulations and plasma corticosterone levels indicate that $5 \mathrm{sec}$ of manipulation increase corticosterone to a comparable level as found after 3-min exposure to a novel environment. One hour after treatment these levels are still substantially elevated (Seggie \& Brown, 1975). In general, $4 \mathrm{hr}$ should be allowed for the corticosterone levels to return to basal after an initial rise induced by exposure to a novel environment (Pfister \& King, 1976). The studies of Bohus (1975) suggest that corticosteroid levels are increased by any treatment rats receive, expecially during the period the presently described grooming test takes place. Stern, Erskine and Levine (1973) found a dissociation between open-field behavior and pituitary-adrenal function. The work of the authors cited above indicates that corticosteroid levels are not closely correlated with the displayed behavior. The present data thus imply that novelty-induced grooming and pituitary-adrenal function are dissociated. 
The temporal pattern of grooming behavior is affected differently by novel environment and preobservation treatment (Fig. 3): i.e., stimuli present before obserwation may enhance the grooming immediately following their removal, while stimuli present during observation can prolong grooming during the observation period. These effects seem to be additive. Results obtained in a twin study (Jolles, Rompa-Barendregt \& Gispen, 1979) indicate that grooming scores are higher when the animals are kept awake during the observation period by a red light or a buzzing sound; scores are also enhanced when the animals are observed in an enriched environment and when barpressing for water in a Skinner box. The state of activation/wakefulness of the animals may then be a very important factor: When the rats are awake as a result of treatment before the observation starts (transport, injection, etc.) enhanced grooming is observed (Figs. I and 3). When kept awake during the observation period (e.g.. by novel simuli) their grooming is prolonged and as a result they have a higher grooming score. Delius (1970) concluded from electroencephalographic studies that displacement activities such as grooming behavior may represent a de-arousal mechanism serving homeostasis. Displacement activities would reflect the output consequence of an activated arousal-inhibiting system. Indeed it was found that pigeons showed drowsiness associated with the EEG signs of lowered wakefulness as a response to a novel environment and a frustrating and fear-producing procedure. This was often accompanied by comfort movements as yawning, stretching, grooming, etc before the birds became active again (Delius, Craig \& Chaudoir, 1976). The results obtained in the present study are in line with such a hypothesis. In 1959, Bindra suggested that displacement activities typically occur when the animal is in state of heightened arousal. He used this term to denote roughly the degree to which an organism is excited rather than calm. Results on displacement grooming obtained in other studies could also be interpreted in this way: grooming as a result of conflict situations (Hinde, 1970), stressful and unexpected stimuli (Fentress, 1968a,b), and frustration (McFarland, 1966) may be the result of the activating potency of these stimuli. Such a view is supported by Fentress (1973) who made clear that there is an endogenous component that is of major importance to the performance of grooming. Furthermore, this interpretation may be of value in elucidating mechanisms of action of ACTH and related pituitary peptides on the brain, in view of their potency to induce excessive grooming (Gispen et al., 1975; Jolles, Rompa-Barendregt, \& Gispen, 1979).

\section{REFERENCES}

Adolph. E. F. (1947). Toleration to heat and dehydration in several species of mammals. American Joumal of Physiology, 151, 564-575.

Bindra, D. (1956). An interpretation of the displacement phenomenon. British Jourhal of Psychology 50, 263-269. 
Bohus, B. (1975). Environmental infuences on pituitary-adrenal systen function. In H. P. Klotz (Ed.), Problemes Actuels d'Endocrinologie et de Nutrition, Serie No. 19. Expansion Scientifique Française. Paris. pp. 55-62.

Bolles, R. J. (1960). Grooming behavior in the rat. Jourral of Comparante and Physiolog. ical Psychology, 53, 306-310.

Broadhurst, P. L. (1960). Experiments in psychogenetics: applications of biometrical genetics to behavior. In H. S. Eysenck (Ed.), Experiments in Personaliry, Vol. 1. pp. 1-102. London: Routledge \& Kegan Paul.

Camnon, W. (1932). The Wisdom of the Body. New York: W. W. Norton.

Colbern, D., Isaacson, R. L., Bohus, B., \& Gispen, W. H. (1977). Limbic midbrain lesions and ACTH-induced excessive grooming. Life Sciences, 21, 393-402.

Colbern, D. L., Isaacson, R. L., Green, E. J., Gispen, W. H. (1978). Repeated intraventricular injections of $\mathrm{ACTH} \mathrm{CH}_{-34}$ the effects of home or novel environments on excessive grooming. Behavioral Biology, 23, 381-387.

Delius I. D. (1970). Irrelevant behavior, information processing and atousal homeostatis. Psychologische Forichung, 33, 165-188.

Delius, J. D. "Craig, B., \& Chaudoir "C. (1976). Adrenocorticotropic hormone, glucose and displacement activities in pigeons. Zeitschrif fir Therpsychologie, 40, 183-193.

Fentress, J. C. (1968). Internupted ongoing behavior in two species of vole (Microtus agrestis and Clethrionomys britiannicus) I: Response as a function of preceeding activity and the context of apparently irrelevant motor pattern. Animal Behaviour. 16, 135-153.

Fentress, J. C. (1968). Interrupled ongoing behavior in two species of vale (Microtus agrestis and Clethrionomys Britianicus) III: Extended analysis of motivational variables underlying fleeing and grooming behavior. Animal Behaviour, 16, 154-167.

Fentress, J. C. (1973). Development of grooming in mice with amputated forelimbs. Science, $179,704-705$.

Gispen, W. H., van der Poel, A. M. \& van Wimersma Greidanus, Tj. B. (1973). Piluitaryadrenal infuences on behavior: Responses to test siluations with or without electric foot shock. Physiology and Behavior, 10, 345-350.

Gispen, W. H., Wiegant, V. M., Greven, H. M., \& de Wied, D. (1975). The induction of excessive grooming in the rat by intraventricular application of peplides derived from ACTH: Structure activity studies. Life Sciences, 17, 645-652.

Hainsworth, F. R. (1967). Saliva spreading activity and body temperature regulation in the rat. American Journal of Physiology, 212, 1288-1292.

Hinde, R. A. (1970). Animal Behovior, a Synthesis of Eihology and Comparative Psychology (2nd Ed.). New York: McGraw-Hill.

van Iersel, J. J. A. \& Bol, A. C. (1958). Preening of two tern species: A study on displacement activities. Behoviowr. 13, 1-88.

Jolles, J., Rompa-Barendregt, J., \& Gispen, W. H. (1979). ACTH-induced excessive grooming in the rat: The infuence of environmental and motivational factors. Hormones and Behavior, 12, in press.

König, J. F. R., Klippel, R. A. (1963). The Rat Brain, a Stereofactic Atas. p. 25. Huntingdon, N.Y.: Krieger.

Mason, J. W. (1968). A review of psychoneuroendocrine research on the pituitary-adrenal cortical system. Psychosomatic Medicine, 30, 576-607.

Mc Farland, P. J. (1966). The role of attention in the disinhibition of displacement activity. Quarterly Journal of Experimentat Psychology. 18, 19-30.

Pfister, H. P., King, M. G. (1976). Adaptation of the glucocorticosterone response to novelty. Physiology and Beharhor, 17,43-46.

Rowell, C. H.F. (1961). Displacement grooming in the chaffinch. Amimal Behoviour. 9, $38-63$. 
Seggie, J. A., \& Brown, G. M. (1975). Sress response pattern of plasma corticosterone. prolactin, and growth hormone in the rat, following handing or exposure to a novel environment. Canadian Journal of Physiology and Pharnacology, 53, 624-637.

Sevenster. P. (1961). A causal analysis of a displacenent actity. Behowour Supplement. 9 , $1,170$.

Siegel, S. (1956). Nomparametric Statistics. pp. 83-87. New York: MeGraw-Hill.

Stern, I. M., Erskine, M. S., \& Levine, S. (1973). Dissociation of open-field behavior and pituitary adrenal function. Hormones and Behavior, 4, 149-162.

Svenson, R. M., \& Randall, W. J, (1977). Grooming behaviour in cats with pontile lesions and cats with tectal lesions. Joumal of Compararive and Physiological Psychology, 91, $313-326$.

Timbergen, N. (1940). Die Übersprungbewegung. Zeirschrif fur Tierpsychologie, 4, 1-40.

Wiggant, V. M. \& Gispen. W. H. (1977). ACTH winduced excessiwe grooming behavior in the rat: Latent activity of $\mathrm{ACTH}_{4-7 .}$ Behavioral Biology, 19, 554-558. 